\title{
The resilience and versatility of acidophiles that contribute to the bio-assisted extraction of metals from mineral sulphides
}

\author{
H.R. Watling ${ }^{1}$, E.L.J. Watkin ${ }^{2}$ and D.E. Ralph ${ }^{3}$
}

Parker Centre for Integrated Hydrometallurgy Solutions: ${ }^{1}$ CSIRO Minerals Down Under Flagship, PO Box 7229, Karawara, Western Australia 6152 (email: Helen.Watling@csiro.au); ${ }^{2}$ School of Biomedical Sciences, Curtin University of Technology, Bentley, Western Australia 6845 (email: E.Watkin@curtin.edu.au); ${ }^{3}$ School of Chemical and Mathematical Sciences, Murdoch University, South Street, Murdoch, Western Australia 6150 (email: D.Ralph@murdoch.edu.au).

For correspondence: Dr Helen Watling, TEL. 6189334 8034, FAX 6189334 8001, Email Helen.Watling@csiro.au

(Received $x x x$; final version received $x x x$ )

\begin{abstract}
In this paper, a brief outline is presented on acidic ferric ion oxidation of mineral sulphides for the extraction of metals in both stirred tank reactors for mineral concentrates and heaps for low-grade ores. The identities and capabilities of the relatively few acidophiles that assist the oxidative processes are summarised and their responses to selected extremes in their growth environments described. Individually, the organisms adapt to the presence of high concentrations of heavy metals and other elements in the bioleaching environment, tolerate a wide range of acidities and can recover from prolonged exposure to temperatures significantly above their preferred temperatures for growth. However, the presence of chloride in their acidic environment presents a significant physiological challenge. Species that exhibit a chemotactic response and attachment to sulphide surfaces, where they can create their own micro environments, would be favoured in both heap bioreactors with low availability of energy substrates and physically aggressive, agitated CSTR environments treating concentrates.
\end{abstract}

Keywords: acidophiles; metals extraction; bioleaching; sulphur oxidation, iron oxidation

\section{Introduction}

Mineral sulphide ores are unstable when exposed to water and oxygen at standard temperature but their oxidation rate is usually very slow, despite being energetically very favourable. This circumstance has led to the evolution of single-celled microbes capable of catalysing the oxidation of sulphides and harvesting the energy to make new cells and modify their environment. Bio-assisted oxidation of mineral sulphide ores is thus a natural phenomenon that often results in 'acidic drainage', where the run-off and seepage through rock dumps and stockpiles contains high concentrations of metals at low $\mathrm{pH}$. While acid drainage is a long-recognised problem, the active participation of bacteria and archaea in the processes of sulphide mineral dissolution has only been described in the last 60 years [1]. Since then, a vast body of literature, comprised of technical research reports and some substantial reviews, has been published. For example, recent understanding of the chemistry and mechanisms of sulphide mineral oxidation and the roles of pyrite $\left(\mathrm{FeS}_{2}\right)$ surface reactivity and of acidophilic microorganisms in acid rock 
drainage were comprehensively summarised [2-6] and the potential opportunities for remediation of acid mine drainage discussed $[2-3,7]$.

A further body of research and review literature has developed in relation to the optimisation and exploitation of similar reaction chemistry and microbiology for the extraction of metals such as copper [8-9], nickel [10-11] and cobalt [12-13] from mineral sulphide ores [10, 14-15] or sulphide concentrates $[13,15-17]$. At the same time, significant advances in understanding the acid-sulphur microcosm have become possible through the development and application of sophisticated physico-chemical measurement techniques and molecular biological methods to fundamental studies on the occurrence and growth of acidophilic chemolithotrophs and chemoorganotrophs in bioleaching reactors [5-6, 18-21].

As in the case of acid mine drainage, the chemistry of sulphide (bio)leaching has been studied in detail for selected 'important' minerals. Klauber [22] reviewed the surface chemistry of acidic ferric sulphate dissolution of chalcopyrite $\left(\mathrm{CuFeS}_{2}\right)$ in respect of hindered dissolution (loosely termed "passivation" in many publications). He concluded that both sulphur and jarosite formation play roles, depending upon (bio)leaching conditions. Sophisticated electrochemical studies using thin films of iron sulphides, combined with TEM visualisation, revealed previously unknown details of microorganismmineral interface interactions, as summarised and discussed by Tibutsch and Rojas-Chapana [23] in the context of semiconductor electrochemistry. Sand et al. [24] proposed that mineral sulphides either dissolved via the thiosulphate mechanism (pyrite, molybdenite $-\mathrm{MoS}_{2}$, tungstenite $-\mathrm{WS}_{2}$ ) or by the polysulphide mechanism (sphalerite — $\mathrm{ZnS}$, chalcopyrite, galena — $\mathrm{PbS}$ ).

Even though sulphide bioleaching comprises a very small component of biotechnology as a whole, there is nevertheless a growing molecular biology-based understanding of the physiology of bioleaching organisms. For example, 16 genomes of bioleaching-related bacteria or archaea have been completed or are in progress [25]. Jerez [26] presents an informative review of the ways in which genomics, proteomics, transcriptomics and metabolomics approaches to understanding how microbial cells operate in their communities are providing new insights into what constitutes a healthy microbial consortium and how that condition may be maintained for more efficient metals extraction during the extended duration of bioleaching operations. 
The scope of this review is intentionally constrained to a re-examination of selected fundamental studies relating to the adaptability of bioleaching organisms to their extreme and changeable environments. Brief descriptions of the physical and chemical conditions prevailing in two types of bioleaching reactors and of the acidophiles thought to assist metals extraction through their abilities to oxidise iron(II) and / or reduced inorganic sulphur compounds (RISCs) are followed by discussions on the impacts of those conditions upon microbial activity and the probable consequences in respect of metals extraction. The reader is referred to the above citations and references therein for more comprehensive accounts of bioleaching chemistry, microbiology, biochemistry and molecular genetics of acidophilic organisms associated with bioleaching.

\section{Bio-assisted metals extraction from base-metal sulphides}

The advantages of bio-assisted leaching technology for the extraction of metals from sulphidic ores are described as moderate capital investment and lower operating costs making the technology potentially applicable to relatively low-grade ores in smaller deposits. The commercial technology has evolved into two modes employing either energy-intensive stirred-tank reactors [12, 27] or extensive (large footprint) irrigated heap-leach operations using either crushed ore [14, 28] or run-of-mine ore [27, 29]. Both stirred tanks and irrigated heaps suffer the disadvantage that bio-assisted leaching is relatively slow compared to currently preferred pyrometallurgical processes. The selection of the appropriate mode for bioleaching depends primarily on the value of the recovered metal. For copper and nickel, heap-leach bioreactors are the preferred commercial technology for low-grade and complex ores [8-11]. Proven continuous stirred-tank technology for the extraction of gold from pyritic concentrates [17] has yet to be applied commercially to the extraction of lower-priced base metals from their concentrates, with the exception of a pyrite-oxidation, cobalt-extraction plant [12].

While the major physical differences between a heap-leach and stirred-tank operation are apparent, the fundamental catalytic processes carried out by the microbes have a common basis independent of the mode of operation. Many of the species that successfully colonise these environments oxidise iron(II) or RISCs, or both, thereby gaining energy to make more cells and catalysing the 
dissolution of the solid mineral sulphide. Other organisms make indirect contributions, for example through the degradation of organic compounds present in the ore or introduced through processing [6]. The chemical and biochemical mechanisms have been intensively studied [30] and much is understood about the key roles played by ferric ions $\left(\mathrm{Fe}^{3+}\right)$ and acid $\left(\mathrm{H}^{+}\right)$in the breakdown of mineral sulphides.

Maximising mineral breakdown, which is the key step in metals extraction, requires the optimisation of a number of factors but maintaining an environment conducive to cell growth and iron(II) and RISC oxidation is of prime importance.

\section{Managed sulphide heaps to process low-grade ores}

Low cost processing technology is necessary for the economic extraction of metals from low-grade basemetal ores. Heap leaching is a simple technology that involves the crushing of ore, the capture of fines and initiation of reaction chemistry via an acid-conditioning process and stacking of a permeable bed onto a prepared pad [14]. The aim is to construct a homogeneous packed bed through which the leachate can percolate evenly. Run-of-mine (ROM) ore leaching is less sophisticated. Ore is dumped by truck onto the leach pad equipped with solution drainage points, holding and solution management ponds and, if required, aeration pipes [29]. There is a broad particle size distribution, the constraint being that boulders fit into trucks, and this size distribution results in a heterogeneous ore bed in terms of mineralogy, sulphide exposure to leachate and solution permeability. In both cases, the top of the heap is irrigated with acidic (usually $\mathrm{pH}<2$ ) solution and air may be blown into the bed via perforated pipes near the base of the heap [31]. For most modern operations the metal-rich leachate is collected from the base of the heap and delivered to a solvent extraction - electrowinning plant.

Heaps are such large entities that it is inevitable that conditions will vary within the bed as a result of changes in ore mineralogy, imperfect aeration and solution distribution through the bed and different reaction chemistry (affecting temperature and $\mathrm{pH}$ ) and kinetics. An important consequence that impacts on the microbial population is the variability in conditions experienced by the cells in their microcosms during the heap's leaching cycle and which can be managed only indirectly and imprecisely via aeration and / or irrigation management. As an example [32] discuss three case histories for 'transiently 
thermophilic' heaps. Leach cycles have long duration, from months to years, and are thus also affected by geographic location and associated seasonal climatic changes. Nevertheless, heap leaching can be sustained and managed in arid, tropical and cold regions [10, 14, 32].

\section{Stirred tank technology to process mineral concentrates}

The stirred tank technology used to process some pyritic gold concentrates [17] has been modified to process base metal concentrates [12, 33-34]. While, initially, most plants were operated in the temperature range $35-40{ }^{\circ} \mathrm{C}$ [35-36], more recent research focus has been on the use of moderate and extreme thermophiles $\left(45-80{ }^{\circ} \mathrm{C}\right)$ to assist metals extraction from sulphide concentrates because, generally, sulphide oxidation by ferric ions usually proceeds more rapidly at higher temperatures [16, 27]. The continuous stirred tank bioreactors (CSTRs) are vigorously aerated, delivering both oxygen and carbon dioxide (the latter may be supplemented) for microbial growth [16].

The distinctive characteristic of the controlled CSTR environment, compared with the heap environment, is that conditions in the primary tanks where most of the biooxidation takes place, once established, are maintained relatively uniform and stable in respect of temperature and solution $\mathrm{pH}$ (often $\mathrm{pH}$ 1.5-2) [35]. However, conditions are more aggressive physically than those of the heap environment, as a consequence of high pulp densities (in the range 12-20\%) and the strong agitation and aeration regime [16, 37-38]. CSTRs and heaps also differ in leachate composition (discussed subsequently).

\section{Leach chemistry}

The reactions involved in mineral sulphide dissolution are acid dissolution and oxidation reactions. Acid dissolution and / or alteration reactions of gangue minerals associated with sulphide ores are also important. Acid dissolution of mineral sulphides at 'moderate' temperatures and atmospheric pressure is generally very slow, the exception being pyrrhotite $\left(\mathrm{Fe}_{1-\mathrm{x}} \mathrm{S}\right.$ where $\mathrm{x}$ varies between 0 and 0.125 , denoted as FeS in this paper - Equation 1). Pyrrhotite can be quite reactive in acidic, oxygenated environments, delivering iron(III) species which persist in solution under acidic conditions. The dissolution of some gangue minerals also yields iron(III) species. Equation 2 represents the dissolution of the silicate biotite 
$\left(\mathrm{K}\left(\mathrm{Fe}^{\mathrm{II}}{ }_{1.5} \mathrm{Mg}_{1.5}\right) \mathrm{AlSi}_{3} \mathrm{O}_{10}(\mathrm{OH})_{2}\right)$, chosen as an example gangue mineral because the reaction also illustrates the sources of some other elements that build up in recycled leach solutions. The presence of a strong oxidant such as ferric ion greatly enhances sulphide dissolution, generating products that include ferrous ion, elemental sulphur (from chalcopyrite — Equation 3) or sulphate (from pyrite — Equation 4).

$$
4 \mathrm{FeS}+9 \mathrm{O}_{2}+2 \mathrm{H}_{2} \mathrm{SO}_{4} \rightarrow 2 \mathrm{Fe}_{2}\left(\mathrm{SO}_{4}\right)_{3}+2 \mathrm{H}_{2} \mathrm{O}
$$

$\mathrm{K}\left(\mathrm{Fe}^{\mathrm{II}}{ }_{1.5} \mathrm{Mg}_{1.5}\right) \mathrm{AlSi}_{3} \mathrm{O}_{10}(\mathrm{OH})_{2}+7 \mathrm{H}^{+}+{ }^{15} /{ }_{4} \mathrm{H}_{2} \mathrm{O}+{ }^{3} / 8 \mathrm{O}_{2}$

$$
\rightarrow \mathrm{K}^{+}+{ }^{3} / 2 \mathrm{Mg}^{2+}+\mathrm{Al}^{3+}+3 \mathrm{H}_{4} \mathrm{SiO}_{4}+{ }^{3} / 2 \mathrm{Fe}(\mathrm{OH})_{3}
$$

$\mathrm{CuFeS}_{2}+2 \mathrm{Fe}_{2}\left(\mathrm{SO}_{4}\right)_{3} \rightarrow 5 \mathrm{FeSO}_{4}+\mathrm{CuSO}_{4}+2 \mathrm{~S}^{\mathrm{o}}$

$\mathrm{FeS}_{2}+7 \mathrm{Fe}_{2}\left(\mathrm{SO}_{4}\right)_{3}+8 \mathrm{H}_{2} \mathrm{O} \rightarrow 15 \mathrm{FeSO}_{4}+8 \mathrm{H}_{2} \mathrm{SO}_{4}$

The key contributions from microorganisms during metal extraction from mineral sulphides are the oxidation of RISCs (Equation 5) and iron(II) species (Equation 6). In this way cells generate additional acid and replenish the ferric ions which can then oxidise more of the sulphides (Equations 3 and 4). These two reactions are also important from a research perspective because they can be used to probe microbial activity in situ under controlled but varied conditions, particularly microbial responses to deliberate excursions outside the preferred growth conditions.

$$
\begin{array}{lr}
2 \mathrm{~S}+3 \mathrm{O}_{2}+2 \mathrm{H}_{2} \mathrm{O} \rightarrow 2 \mathrm{H}_{2} \mathrm{SO}_{4} & \text { acid generating } \\
4 \mathrm{FeSO}_{4}+2 \mathrm{H}_{2} \mathrm{SO}_{4}+\mathrm{O}_{2} \rightarrow 2 \mathrm{Fe}_{2}\left(\mathrm{SO}_{4}\right)_{3}+2 \mathrm{H}_{2} \mathrm{O} & \text { acid consuming }
\end{array}
$$

One further group of reactions plays an important role in leach chemistry. Iron chemistry is inextricably linked with acidity (solution $\mathrm{pH}$ ) in leaching systems. Some acidophiles are very efficient at oxidising ferrous ions to ferric ions (Equation 6) which, in solutions containing substantial concentrations of sulphate ion together with a variety of other cations, form insoluble iron(III) oxides, hydroxides, sulphates and / or hydroxysulphates. The actual species or mixtures of species formed is influenced by the prevailing leachate composition and $\mathrm{pH}$, and include:

- Ferrihydrite, approximate formula $5 \mathrm{Fe}_{2} \mathrm{O}_{3} \cdot 9 \mathrm{H}_{2} \mathrm{O}$, mainly formed in solution $\mathrm{pH}>5$.

- Goethite, $\mathrm{FeOOH}$, formation promoted in solution $\mathrm{pH}>4$ and lower sulphate concentrations.

- Schwertmannite, $\mathrm{Fe}_{8} \mathrm{O}_{8}(\mathrm{OH})_{6} \mathrm{SO}_{4}$, a poorly crystalline phase, formed in ferric sulphate solutions low in monovalent cations; slowly transformed to goethite. 
- Jarosite (Equation 7), formation promoted at $\mathrm{pH}$ 1.7-2.3, higher sulphate and ferric ion concentrations and the presence of monovalent cations.

$3 \mathrm{Fe}^{3+}+2 \mathrm{SO}_{4}{ }^{2-}+6 \mathrm{H}_{2} \mathrm{O}+\mathrm{M}^{+} \rightarrow \mathrm{MFe}_{3}\left(\mathrm{SO}_{4}\right)_{2}(\mathrm{OH})_{6(\mathrm{~s})}+6 \mathrm{H}^{+}$where $\mathrm{M}=\mathrm{K}^{+}, \mathrm{Na}^{+}, \mathrm{NH}_{4}{ }^{+}$or $\mathrm{Ag}^{+}$

These compounds are important because their formation depletes the leachate of ferric ions, impacting on the consequent production of ferrous ions (Equations 3 or 4), the energy source for the ironoxidising organisms (Equation 6). Ferric ion depletion in the leachate may also affect the continued oxidation of some sulphides. In columns charged with a net acid-consuming, complex pentlandite $\left(\mathrm{Fe}, \mathrm{Ni}_{9} \mathrm{~S}_{8}\right)$-chalcopyrite-pyrrhotite ore, ferric ion was clearly required for chalcopyrite oxidation but pentlandite dissolution continued in the presence of low ferric ion concentrations $(<100 \mathrm{mg} / \mathrm{L})$ [39]. In subsequent ancillary tests it was shown that covellite $(\mathrm{CuS})$ dissolution also required a significant ferric ion concentration $(\sim 1000 \mathrm{mg} / \mathrm{L})$ [40]. These results are consistent with those of an electrochemical study on the oxidative leaching of chalcopyrite, chalcocite $\left(\mathrm{Cu}_{2} \mathrm{~S}\right)$ and covellite [41].

\section{Iron- and sulphur-oxidising acidophiles}

In recent years, with the benefit of molecular biological techniques, there has been a rapid increase in the numbers of identified microorganisms inhabiting acidic environments. Nevertheless, there are still relatively few identified species (e.g., [6]). More specific to the present work, are the smaller number of iron(II)- and / or RISC-oxidising acidophiles (Table 1), some of which have been isolated from heaps (both crushed and ROM ore) and CSTRs treating mineral sulphides or putatively identified as present using culture-independent molecular techniques.

Of the 35 identified species, eight oxidise iron(II) but not RISCs, 11 oxidise RISCs but not iron(II) and a further 16 have the ability to oxidise both energy sources. Only 24 of the species listed, mostly mesophiles and moderate thermophiles, have been identified thus far in heaps of low-grade ore (crushed or ROM) or in CSTRs processing mineral sulphide concentrates. Many of the thermophiles were originally retrieved from acidic geothermal springs and solfataras [6] and are apparently not naturally present in ambient-temperature sulphide ore deposits, although some have been cultured in CSTRs if appropriately hot conditions are maintained (Table 1). 
Numerous studies have utilised Acidithiobacillus ferrooxidans, largely due to the ease with which laboratory cultures could be maintained and also because several years passed after its description before further species in sulphidic leaching environments were isolated and described. Thus, for many years, At. ferrooxidans was thought to be the main contributor to enhanced metals extraction during sulphide leaching. This is no longer the case. It is increasingly recognised that attributes peculiar to different species offer advantages in different bioleaching systems. For example, the Leptospirillum spp. only utilise iron(II) as energy source, but this constraint is compensated by their ability to tolerate lower solution $\mathrm{pH}$ and higher concentrations of iron(III) than At. ferrooxidans, giving them an advantage in CSTRs for the treatment of pyritic gold concentrates [70]. Similarly, with improved methodology making it possible to distinguish Acidithiobacillus caldus from Acidithiobacillus thiooxidans, the prevalence and, in some cases, dominance of At. caldus in CSTRs is now more widely recognised [18, 70]. The Sulfobacillus spp. can grow as chemolithotrophs, mixotrophs and / or heterotrophs in aerobic and anaerobic environments for at least short periods of time and their ability to form spores confers an added advantage in sulphidic leaching environments [71]; in the past, their contributions to bioleaching have seemed to be under-valued. Similarly, the acidophilic Alicyclobacillus species, some of which have been shown to oxidise iron(II) and RISCs [72], are increasingly being identified in sulphidic environments. They are heterotrophs and probably benefit the biomining organisms by degrading organic compounds [6]]. Like the Sulfobacillus spp., Alicyclobacillus spp. form spores which would contribute to their survival in extreme environments. In many cases the oxidation of iron(II) and / or RISCs by Alicyclobacillus species has not been tested [72] and these capabilities may be more widespread than is currently supposed.

\section{Microbial responses to changing environments}

As mentioned above, CSTRs offer a controlled environment in respect to agitation, aeration, temperature, $\mathrm{pH}$ and metals concentrations, not dissimilar to the conditions imposed during many laboratory experiments. In comparison, the heap environment is very variable, not easily controlled with any degree of precision and able to be monitored only indirectly through physical and chemical measurements of 
leachates exiting the base of the heap or via probes (resistant to acid attack) placed during heap construction. The presence, functions and activity of species in samples from sulphide leaching reactors are a current topic of interest [68, 73-75], supplementing many fundamental studies on the growth, iron(II) and RISC oxidation by individual species or undefined mixed cultures.

\section{Tolerance to metals and other cations}

Elemental concentrations in acidic drainage from mines or other sulphur-rich deposits vary enormously depending upon the mineral composition of the deposit and the acidity of the water [76-77]. Bioleaching operations constitute extreme examples of 'acid drainage'. The metals concentrations in leachates differ between heaps and CSTRs (Table 2), with higher base metals concentrations in CSTR leachates for the processing of concentrates and higher 'gangue-mineral' elements in heap leachates. These approximate upper-limit concentrations have been collated from the sparse and often incomplete elemental data in the public domain, personal communications and in-house laboratory analyses of samples which may not be identified [12, 34, 78-79]. The data provide a useful bench-mark against which the relevance of metals tolerance testing data can be measured.

Not surprisingly, most published data on metals tolerances relate to the impact of metals on ferrous ion oxidation by At. ferrooxidans, the large number of studies permitting some generalisations to be made:

- Different base metal cations inhibit ferrous ion oxidation to different extents where the same experimental method and bacterial strain are applied in comparative tests [80]. The broad variation between different At. ferrooxidans strains (i.e., by different researchers) is such that it is hard to make direct comparisons or assign a general ‘rank order of inhibition'. Silver, mercury, chromium, and metal anions (e.g., arsenate, molybdate) tend to be among the more inhibitory cations or anions [81-82].

- Large variations in metals tolerance have been reported for native At. ferrooxidans strains sourced from different habitats [83-84]. 
- Adaptation (orders of magnitude) can be effected by repeated subculture or just long-term growth in the presence of high metal concentrations [85-86].

Few data are available for other species, for example, At. caldus [53, 87], Leptospirillum [88-89], Acidimicrobium [53], Sulfobacillus [53, 90], Acidiphilium [91], Ferroplasma [92-93], Sulfolobus [94], Metallosphaera [95]. However, it seems reasonable to assume that, were sufficient data available for each of the relevant acidophilic strains, similar generalisations would hold as for At. ferrooxidans, though the effective base metals concentrations would differ in each case. Metals resistance mechanisms in bacteria and, more specifically acidophiles are outside the scope of this paper but have been reviewed by Silver and Phung [96], Dopson et al.[97] and Rawlings [98] and are the subject of recent studies using sophisticated molecular biology techniques [e.g., 99-100].

It is generally believed that microbial cultures enriched from ore deposits contain the best-adapted strains for that ore, the implication being that metals extraction would be enhanced in the presence of tolerant, adapted strains. However, in a recent study it was found that superior tolerance to high metals concentrations, while conferring the advantage of survival in extreme environments, was not necessarily accompanied by enhanced extraction of metals [53]. This result suggests that other factors control the rates and extent of metals extraction from sulphide minerals and that bacterial activity is not rate limiting as long as the bacteria are present and active in oxidation.

Other elements which can increase to high levels in recycled heap leach liquors are aluminium and magnesium (Table 2). Fewer data are available on the impact of these on iron(II) or sulphurbiooxidation. The results of a study on the impact of aluminium on a mixed mesophilic culture showed that aluminium ions did not exert any direct metabolic effect on iron(II)-oxidising cells but concentrations $>2 \mathrm{~g} / \mathrm{L}$ had an inhibitory effect similar to other background electrolytes [101-103]. Consistent with the above, increased aluminium and sulphate concentrations did not impact on column biodiversity during the leaching of a low grade copper ore colonised by a mixed native consortium [104]. In one study, magnesium ions were shown to impact on iron(II) oxidation by At. ferrooxidans such that, at $15.5 \mathrm{~g} / \mathrm{L}$, oxidation slowed by about $15 \%$ and at $20.5 \mathrm{~g} / \mathrm{L}$ oxidation ceased [105]. In another study, magnesium in the range $0-10 \mathrm{~g} / \mathrm{L}$ only slightly impacted on ferrous ion oxidation by $L$. ferriphilum but in 
this case aluminium severely depressed both microbial growth and oxidation rates; from these results, Ojumu et al. [106] concluded that ferrous ion biooxidation was only sufficiently inhibited as to affect heap leaching at concentrations greater than $1 \mathrm{M}$ ionic strength. However, estimated ionic strengths for CSTR and heap leachates (derived from leachate compositions used in Table 2 compilation) are significantly higher than one molar (Table 3). Thus it must be assumed that in full-scale bio-assisted leaching operations the microorganisms assisting metals extraction are not performing optimally.

\section{Tolerance to chloride}

In general, chloride in leachates inhibits growth, iron(II) and sulphur oxidation by bioleaching microorganisms [94, 107-108]. Sensitivity of acidophiles to chloride is a pH-dependent phenomenon and the mechanisms are complex; put simply, the presence of the anion leads to acidification of the cytoplasm of the cell when the growth medium or environment has low $\mathrm{pH}[107,109-110]$. This chloride sensitivity restricts the use of seawater and saline bore water for leaching operations where 'fresh' water is not readily available, such as in the Western Australian goldfields. It also impacts where the ores contain chloride, for example as the copper mineral atacamite $\left(\mathrm{Cu}_{2} \mathrm{Cl}(\mathrm{OH})_{3}\right)$ found in the Chilean copper belt. Very few halo-tolerant, acidophilic, iron(II) and / or RISC-oxidising species have been described (Table 4).

Some halo-tolerant, iron(II)-oxidising species have been isolated from marine geothermal springs but were found to grow preferentially in media without sodium chloride addition with optimal $\mathrm{pH} 2$ and temperature $37^{\circ} \mathrm{C}$. They form a group of Thiobacillus prosperus-like strains which can oxidise both iron(II) and RISCs and utilise mineral sulphides, with varying degrees of efficiency [95, 111]. Some strains phylogenetically related to Alicyclobacillus spp. have been enriched from marine sediments and found to oxidise iron(II) best in the presence of $1 \% \mathrm{NaCl}$ [112]. Halophilic isolates from marine environments that require the presence of sodium chloride for growth and can oxidise iron(II)- and / or RISCs have been reported; one RISC-oxidiser (strain $\mathrm{SH}$ ) was reported to be very closely related to Acidithiobacillus thiooxidans [113-114]. The Halothiobacillus spp. are true halophiles that can oxidise RISCs but the combination of high salinity and low $\mathrm{pH}$ (high acidity) appears to present too great a 
challenge for bacterial physiology [115-116]. Their preference of $\mathrm{pH}>6$ for growth is somewhat higher than would be useful in bio-assisted metals extraction.

Shiers et al. [103] showed that adaptation to the presence of chloride was very limited for a mixed mesophilic culture. A modest concentration of $0.7 \% \mathrm{NaCl}$ reduced cell replication by $50 \%$ and no significant culture adaptation or habituation was observed with prolonged exposure to that concentration. In more recent work, in which the growth and iron(II)-oxidation of six acidophiles were compared in the presence of different concentrations of $\mathrm{NaCl}$ it was found that none of the strains tested was as sensitive to the presence of chloride as At. ferrooxidans [108]. A mixed consortium of organisms enriched from acidic drain samples $(\mathrm{pH} 2)$ in the Western Australian wheat belt (Figure 1) was shown to grow optimally and oxidise iron(II) in the presence of $1.25 \% \mathrm{NaCl}$, almost twice the concentration tolerated in the interspecies comparative tests. Iron(II) oxidation at 3\% but not $4 \% \mathrm{NaCl}$ was observed. Four cell types were visible in the mixed consortium; these were subsequently found to be Acidimicrobium-like organisms (two strains) and Thiobacillus prosperus-like organisms (two strains). Attempts are now being made to isolate and characterise the strains and assess their ability to enhance metals extraction from mineral sulphides in saline leaching media.

\section{Changes in temperature}

The strong effect of temperature on iron(II) and sulphur oxidation by acidophiles is well established [117], particularly the rapid decline in activity at only a few degrees above their optimum temperatures for growth. In contrast to CSTRs, temperature changes are characteristic of managed sulphide heaps, particularly at start-up when the highest sulphide content is present. In some heaps, intermittent fluctuations of sufficient magnitude to impact on microbial growth and activity occur as a result of a number of factors, including sulphide mineralogy and reactivity, and aeration and solution management strategies (Figure 2). However, feed solutions to the tops of heaps and leachates exiting the bases of heaps have significantly lower temperatures, moderating the effects of high heap temperatures on the microbial population. Most of the bioleaching species found in heaps are mesophiles or moderate thermophiles (Table 2). 
Without identifying the archaeal organism(s) in the inoculum, Batty and Rorke [118] described the conversion of the bacterially-assisted mesophile-moderately thermophilic CSTR technology to thermophilic technology $\left(78{ }^{\circ} \mathrm{C}\right)$ and its commercial demonstration. The concentrate was ground to $80 \%$ passing $38 \mu \mathrm{m}$ [16], providing ample exposed surface for oxidative sulphide dissolution. The thermophilic culture was found to exhibit better copper tolerance (inhibition started at $35 \mathrm{~g} / \mathrm{L}$ ) but greater shear sensitivity, necessitating operation at lower pup density (12.5\%) [118]. A key advance during the development was the significantly increased efficiency in oxygen utilisation [27].

In the history of heap bioleaching, most of which pertains to the active development of heaps of low-grade, crushed ore [14], heap inoculation has been achieved through colonisation by indigenous flora which can participate in the two key reactions (Equations 5 and 6). In some instances strategies to promote colonisation have been employed, such as the addition of nutrients to solutions and the creation of conditions that result in increased iron concentrations [28] or the preparation and delivery of mixed cultures either during the agglomeration process and/or irrigated directly to the top of the heap [119-120]. A recent informative review discusses aspects of developing mixed microbial consortia to provide sufficient diversity for optimum performance during the life of a heap [121]. While the focus of that review is mainly on ambient to moderate temperature leaching using bacterial consortia, the underlying requirements for higher temperature leaching, being sufficient biodiversity for all points in the temperature and $\mathrm{pH}$ ranges, would still hold for hot heaps.

The interest in operating hot heaps, together with the knowledge that hyperthermophiles do not grow well in ambient temperature ores, is the driver for developing archaeal inocula and systems for their delivery at the appropriate time in the life cycle of a heap. The inefficiency of cell distribution to all depths of heaps when an inoculum is added via the irrigation system has been noted [16] and a novel delivery system to overcome this inefficiency proposed [122]. Nevertheless, inoculum delivery-viairrigation has been successfully applied to heaps of refractory gold ore containing between 1-2.5\% sulphur content as sulphide (pyrite and arsenopyrite - FeAsS) [120]. When field trials were conducted, temperatures of up to $80{ }^{\circ} \mathrm{C}$ were measured in some areas of the heaps, indicating that thermophiles might assist sulphide oxidation. Initially, the heaps were inoculated with bacterial mesophiles and 
moderate thermophiles, but after six months of operation, thermophilic Acidanus and Metallosphaera species were added to the biosolution pond and were both subsequently detected in heap samples, indicating successful colonisation. During the development of this technology, a comparative study was undertaken on the response of microbial systems for the heap biooxidation of refractory gold ores to thermal stress [123]. In that study, columns charged with sulphidic gold ore (1.8\% pyrite) were operated isothermally at selected temperatures: $20-23{ }^{\circ} \mathrm{C}$ and $35{ }^{\circ} \mathrm{C}$, both inoculated with At. ferrooxidans and $L$. ferrooxidans; $50{ }^{\circ} \mathrm{C}$, inoculated with S. thermosulfidooxidans; $60{ }^{\circ} \mathrm{C}$, inoculated with Acidianus and Metallosphaera species. An additional column, inoculated with equal numbers of all the above species was operated with periodic increases in temperature from 20 to $60{ }^{\circ} \mathrm{C}$ over an eight week period and subsequent temperature decreases. Key results for the variable temperature column were that mesophiles did not grow at $50-60{ }^{\circ} \mathrm{C}$, although a small population maintained in the ambient temperature feed reservoir subsequently colonised the ore when the column temperature was lowered; the moderate thermophiles increased in number as the temperature was raised to $50{ }^{\circ} \mathrm{C}$ but declined at $60{ }^{\circ} \mathrm{C}$; and the thermophiles did not increase in numbers until the column temperature was raised to $50{ }^{\circ} \mathrm{C}$ and above and this population decreased when the column temperature was lowered.

In our experience it has proved difficult to achieve colonisation of ores by thermophiles with inocula containing thermophilic archaea, even though those species grow on the same ground ores in small-scale flask cultures. For example, Acidianus brierleyi included in a mixed inoculum with At. ferrooxidans, L. ferrooxidans and S. thermosulfidooxidans failed to develop a robust population in columns charged with a low-grade ore containing chalcopyrite $(3 \%)$, pyrite $(2 \%)$ and covellite $(1 \%)$. The temperature-controlled columns were operated with recirculating heated leachates, both subjected to temperatures ramped at one degree per day from ambient to $60{ }^{\circ} \mathrm{C}$ and subsequently held at $60{ }^{\circ} \mathrm{C}$. This temperature regime was imposed to imitate the relatively rapid rise in temperature experienced with this ore during the stacking and curing period of heap construction and was intended to show whether archaea introduced during acid conditioning would colonise the ore once it reached temperatures closer to their preferred temperatures for growth. Temperature profiles of the microorganisms in leachates at the end of the experiment (117 days) indicated colonisation by moderately thermophilic bacteria with preferred 
temperatures for growth in the range $43-55^{\circ} \mathrm{C}$ but not archaeal thermophiles (profile conditions $>60{ }^{\circ} \mathrm{C}$ ). Subsequent analyses of phospholipid fatty acids and ether lipids (indicators of biomass and biodiversity) present in samples extracted from leach residues indicated that the dominant organisms were bacteria $(\sim 95 \%)$ and archaea $(\sim 5 \%)$. In a related experiment, isothermal columns charged with a low grade chalcopyrite ore $\left(\sim 1.5 \% \mathrm{CuFeS}_{2} ; 0.5 \% \mathrm{FeS}_{2}\right)$ and inoculated with a mixed culture were operated from the outset at the selected temperatures. However, in this case the recirculating leachate was at ambient temperature, as is usual in heap operations. Neither Aa. brierleyi nor Metallosphaera hakonensis, the two thermophiles included in the mixed inoculum, were detected in leachate exiting the $60{ }^{\circ} \mathrm{C}$-column after 275 days of operation; nor were they found on the ore when the column was sampled [124]. Escobar et al. [104] conducted a similar experiment in which a column charged with low-grade copper ore with $1.58 \%$ copper; copper bearing minerals were chalcocite, covellite and chalcopyrite (proportions 73:13:14). The column was not deliberately inoculated. It was operated at increased temperature up to $65{ }^{\circ} \mathrm{C}$ with the recycled feed at ambient temperature. Using DNA-based molecular methods, these authors 'identified' mesophilic bacterial strains in the diverse microbial population which decreased in abundance in the leachate when the column temperature was raised. Archaeal thermophilic species were present but with very low abundance. The results above are consistent with what is generally held about thermophilic acidophiles; they do not grow well at temperatures below $45-50{ }^{\circ} \mathrm{C}[117,123]$ and are not expected to dominate bioleaching heaps unless those heaps are inoculated or managed such that temperatures reach and are sustained at temperatures above $50{ }^{\circ} \mathrm{C}[120,123]$.

Given that heaps can vary significantly in temperature and that bacteria in heaps are either immobilised by being attached to the ore or will pass slowly through any 'hot zones' with the percolating solution, the impact on bacteria of heat treatment at temperatures above their optimum as a function of time is of interest because it provides the heap manager with an indicator of the duration of an 'operating window' in which excursions above preferred heap temperatures can be countered by control measures. Studies on the mechanisms by which microorganisms respond to heat stress are numerous but outside the scope of this review [e.g., 125-126]; a few focus on bioleaching acidophiles [127-130]. Heat shock at $35{ }^{\circ} \mathrm{C}$ for as little as one hour duration induced thermotolerance in At. ferrooxidans grown at $20{ }^{\circ} \mathrm{C}$, 
resulting in a 1000-fold increase in viable cells during growth at $42{ }^{\circ} \mathrm{C}$ compared with a non-shocked control [131]; the authors noted that the thermotolerance was immediate and sustained for the duration of the high temperature growth study. Modak et al. [132] induced thermotolerance in At. ferrooxidans by repeated sub-culture in ferrous ion growth medium at increasing temperatures from $30{ }^{\circ} \mathrm{C}$ to $42{ }^{\circ} \mathrm{C}$. Their results demonstrated that At. ferrooxidans adapted to moderately thermophilic bioleaching conditions with pyrite as energy substrate but that the thermotolerance was lost if the adapted strains were subsequently cultured at lower temperatures. While subjected to prolonged heat treatment at $45{ }^{\circ} \mathrm{C}$, about seven degrees higher than its preferred growth temperature of $38.6^{\circ} \mathrm{C}$, the test strain of $L$. ferriphilum did not oxidise ferrous ions, consistent with the literature [117]. However, once the incubation temperature was lowered to $35^{\circ} \mathrm{C}$, close to its preferred growth temperature, L. ferriphilum recommenced ferrous ion oxidation (Figure 3). The duration of the heat treatment, the only variable in these experiments, appeared not to be the key factor influencing the lag period prior to the onset of ferrous ion oxidation. Greater understanding of the physiological mechanism of induced thermotolerance may provide an explanation in the future. This line of research is being expanded to include other species to test their endurance in respect of transient exposure to high temperatures in heaps. The demonstrated acquisition of thermotolerance in At. ferrooxidans [131-132] and the recovery of activity in L. ferriphilum after prolonged exposure to moderately thermophilic temperatures are positive attributes in the context of heap bioleaching, where residence times can be of the order of days. The attributes also provide insights into the unexpected detection of bacteria outside their expected temperature range.

\section{Changes in acidity (pH)}

For recent comprehensive reviews of the physiological challenges faced by acidophiles and the mechanisms they may use to overcome those challenges, the reader is referred to Baker Austin and Dopson [133], Slonczewski et al. [134] and Ferguson and Ingledew [110]. In this paper, the focus is on the impacts of changing $\mathrm{pH}$ in heap leaching on microbial activity, specifically iron(II) and RISC oxidation. 
Several of the Chilean heap bioleaching operations listed by Brierley [15] are among the 30 leading sulphuric acid consumers in Chile [135]. Most other heap bioleaching operations are also acid consuming, inferred from sparse references on the World Wide Web to acid costs or solution $\mathrm{pH}$. The Monywa operation in Myanmar is acid generating [32] and the Skouriotissa operation in Cyprus may be acid generating due to high reactive pyrite content [136].

The acid dripped or sprayed onto a heap surface percolates through a bed of gangue minerals which may adsorb protons (a rapid process) and / or undergo alteration or dissolution reactions (rapid, moderate or slow reaction rates). Overall, acid consuming reactions cause the solution $\mathrm{pH}$ to rise as a function of depth in a heap. However, acid consumption may be countered in localised environments by the oxidation of an ore component which generates acid, for example reactive pyrite minerals (Equation 4). Fluctuations and localised differences in $\mathrm{pH}$ impact on the activity of biomining organisms, which grow best in quite a narrow range of solution $\mathrm{pH}$ and, during excursions outside that range, are significantly less active in respect of iron(II) and RISC oxidation. Plumb et al. [137] monitored the growth and oxidation rates of iron(II) or elemental sulphur for selected microorganisms and showed large variations in their responses to both high and low solution $\mathrm{pH}$. Such variability is well documented [138] and contributes to relatively rapid changes in heap microbial populations as a function of location and time. Yahya and Johnson [139] demonstrated the significant acid-tolerance of a Sulfobacillus-like strain L-15 in comparison with two iron-oxidising mesophiles. In their experiment, changes in the population occurred within a few days of a change in imposed solution $\mathrm{pH}$. Similarly, using a culture independent method, Liu et al. [140] showed that a Sulfobacillus-like strain had superior tolerance to increased acidity ( $\mathrm{pH}$ 0.9) compared with Leptospirillum- and Acidithiobacillus-like strains obtained from a copper bioleaching plant and grown on pyrite.

When a defined mixed culture with equal numbers each of At. thiooxidans, At. ferrooxidans, L. ferriphilum and F. acidiphilum was grown in basal salts/ferrous ion/tetrathionate/yeast extract media prepared at different $\mathrm{pH}(\mathrm{pH} 0.8,1.4,1.8$ and 2.2), the proportions of the four species changed within two days, with no further significant changes being observed after that time. At pH 0.8 the L. ferriphilum and F. acidiphilum dominated the culture for the duration of the experiment (14 days). At $\mathrm{pH} \mathrm{1.4,} \mathrm{the}$ 
proportion of $F$. acidiphilum had diminished and the Acidithiobacillus spp. increased, and at $\mathrm{pH} 1.8$ and 2.2 the Acidithiobacillus spp. were the dominant component of the mixed culture (Watkin, unpublished data). The results are consistent with published data indicating that the optimum $\mathrm{pH}$ for growth $\left(\mathrm{pH}_{\mathrm{OPT}}\right)$ of Acidithiobacillus spp. ( $\mathrm{pH} 2-3$ ) is higher than that for both L. ferriphilum (pH 1.4-1.8) and F. acidiphilum ( $\mathrm{pH} 1.3-2.2)[49,137,141]$. Indeed, F. acidiphilum has been shown to grow in media as low as $\mathrm{pH} 0.3$ [141], making it remarkably well equipped to assist in metals extraction. Depending upon whether iron(II) oxidising organisms are favoured by changes in $\mathrm{pH}$, as in both the examples given, changes in heap populations will also impact upon metals extraction through the regeneration (or not) of iron(III), the main oxidising agent (Equations 3-4).

\section{Changes in leaching microcosms}

In addition to considering the effects that solution variables have on the activity of acidophilic cells it is worthwhile considering the longer term development of the bio-assisted metal extraction environment.

CSTR operations are structured to achieve consistent but different conditions at each stage of the process. The mineral sulphide is usually beneficiated by gravity or flotation concentration and is of uniform particle size, initially giving a uniform surface area loading. The concentrate feed to the reactors provides an abundant and continuously replenished source of energy for the growth of chemolithotrophic cells whose activities breakdown the mineral sulphide. With passage through a train of primary and secondary reactors, changes arise from the accumulation of soluble components of both sulphide and gangue mineral dissolution (Equations 2-4) and of insoluble reaction products such as iron oxides and sulphur (Equations 3 and 7) which may form in situ on mineral surfaces and possibly hinder further mineral dissolution [142-143].

Limited residence times in each of the CSTRs of a biooxidation or bioleaching plant result in the selection of organisms that can grow the fastest or compete for favourable substrates. As a consequence of long-term operation under these steady state conditions, different cell types dominate the two niches in each reactor; planktonic cells freely suspended in the bulk solution and adsorbed or attached cells occupying, more or less permanently, a mineral surface site [98]. Relatively few studies on the 
composition of microbial populations in CSTRs have been reported [e.g., 52, 144], and even fewer provide comparative data for planktonic and sessile cells. Foucher et al. [63] found that initially $L$. ferrooxidans dominated the sessile population in a reactor treating cobaltiferous pyrite but At. caldus dominated the planktonic population; as the populations evolved, L. ferrooxidans became dominant in both planktonic and sessile populations. The notable similarity among these studies is the limited biodiversity.

The growth of cells from the fixation of $\mathrm{CO}_{2}$ results, ultimately, in a build up of reduced carbon compounds in the water circuit. Both At. ferrooxidans and At. thiooxidans were shown to excrete organic compounds into their growth media [145-146]. This organic material, consisting of a phospholipid related to phosphatidylinositol and keto acids (predominantly pyruvic acid), accumulated to growthinhibiting concentrations when At. thiooxidans was grown on sulphur [147]. Some cells found in the acidophilic habitat have heterotrophic ability and almost certainly convert reduced carbon back to $\mathrm{CO}_{2}$. In comparative batch-culture studies of pyrite oxidation using defined mixed cultures of acidophiles, it was found that dissolved organic carbon increased to $\sim 100 \mathrm{mg} / \mathrm{L}$ in pure culture of Leptospirillum MT6 or mixed culture of Leptospirillum MT6 and At. caldus KU; in pure cultures of At. caldus KU, which did not oxidise the pyrite, the concentration was only $\sim 20 \mathrm{mg} / \mathrm{L}$ [148]. In a comparative study, it was shown that the growth of iron(II)-oxidising heterotrophic acidophiles had minimal requirements for organic carbon (yeast extract $0.02 \% \mathrm{wt} / \mathrm{vol}$ ) and might be satisfied by the organic originating from indigenous autotrophs and / or such sources as soil leachates [149]. While cell death rates due to organics, the degrees of inhibition of such organics or the rates at which reduced carbon material is excreted from live cells are not yet known, insights gleaned from bioleaching tests using defined mixed cultures are contributing to a developing understanding of carbon balance in bioleaching environments.

The heap leach environment presents a big 'energetic challenge' to chemolithotrophic cells such as At. ferrooxidans [110]. The energy available in the solution is from the oxidation of ferrous ions and this can be quite low by comparison with a tank operation, particularly during heap start-up. Low ferrous concentrations mean fewer cells can be made and the production of ferric ion (the oxidant - Equations 3 \& 4) is slow to accelerate. Energy from the solid phase, per mole of mineral sulphide (including 
intermediate RISC reaction products), is similar to that available from a mineral undergoing a tank leach but the mineral sulphide grades in heap leach ores are often an order of magnitude lower than grades in sulphide concentrates. In addition, particle sizes in heaps are usually millimetres in diameter rather than microns and, initially, significant amounts of the sulphide are occluded by gangue minerals, meaning that the available sulphide grades can be two orders of magnitude lower than the nominal ore grade (Figure 4).

For a cell to take greatest advantage of the mineral sulphide energy sources in a heap, it must first locate and attach to the sulphide surface. Attachment is mineral and site specific [8]. Chemotaxis in biomining organisms has been reviewed [150] and recently, comparative genome analyses for At. ferrooxidans, At. thiooxidans, At. caldus and Leptospirillum species have revealed sequences pertaining to chemotaxis [151-152].

Studies, mainly using pyrite as the model sulphide and At. ferrooxidans as the test species, have shown the importance of cells adhering to the mineral surface and the catalytic role played by the extra cellular polysaccharide (EPS) substances excreted by the cells [153]. Studies focused on the attachment of At. ferrooxidans and At. caldus to pyrite and arsenopyrite [154-155] are particularly relevant to the bioleaching of refractory gold ores in which the gold is often occluded within pyrite or arsenopyrite grains [156]. Comparative studies on the attachment of At. ferrooxidans to pyrite, chalcopyrite, sphalerite $(\mathrm{ZnS})$ and pyrrhotite showed that pyrrhotite was preferentially colonised [157], an important result in respect of the heap leaching of complex pyrrhotite-rich ores [39]. When the attachment of At. ferrooxidans, At. thiooxidans and Leptospirillum sp. to chalcocite, pyrite or chalcopyrite surfaces was compared, it was found that most cells attached to pyrite and chalcopyrite with little colonisation of chalcocite and that Leptospirillum cell numbers were always lower than the two Acidithiobacillus species for all minerals [158], a result which is particularly relevant to chalcocite heap leach operations. Even closely related strains of acidophilic bacteria favoured different surfaces for attachment (glass, pyrite, ferric hydroxysulphate precipitate) [159], a key point in that study being the finding that many of the organisms tested did not attach to ferric hydroxysulphate precipitates, relevant to both CSTR and heap bioleaching. 


\section{Summary}

The environment of bio-assisted oxidation of sulphide minerals is on the periphery of both hydrometallurgy and biotechnology. It is a natural process that is exploited commercially with varying degrees of efficiency for the extraction of metals from low-grade ores which are otherwise uneconomic to process and from refractory sulphide concentrates. The acidophiles which participate in the key reactions of iron(II) and RISC oxidation are a robust and versatile subset of those which contribute to acid rock drainage. They can tolerate high concentrations of base metal cations and other elements which enter their environment via the dissolution of gangue minerals and survive short-duration excursions to high temperatures or low $\mathrm{pH}$. Populations, typically low in bio-diversity, adapt to highintensity CSTRs with high pulp densities of sulphide concentrates, strong agitation (potential physical abrasion) and solutions of high ionic strength. Similarly, populations adapt to low-energy environments with minimal available sulphide, a preponderance of gangue minerals, variable $\mathrm{pH}$ and temperature and equally high ionic strength solutions. Microorganisms that exhibit a chemotactic response and attach to sulphide surfaces would be favoured in such environments. Even in a bulk environment over which the operator has limited control, these organisms can create their preferred growth conditions in microcosms at the mineral surface.

\section{Acknowledgements}

D. Collinson, F.A Perrot, D.W Shiers and CM Zammit are thanked for ancillary data and photographs. P Nichols and J. Gibson are thanked for lipids analyses of column residues. The financial assistance of the Australian Government through CSIRO Minerals Down Under Flagship and the Parker Centre for Integrated Hydrometallurgy Solutions is gratefully acknowledged.

\section{References}

1. Colmer, A.R. and Hinkle, M.E. The role of microorganisms in acid mine drainage: A preliminary report. Science 196, 253-256 (1947).

2. Egiebor, N.O. and Oni, B. Acid rock drainage formation and treatment: a review. Asia-Pacific Journal of Chemical Engineering 2, 47-62 (2007). 
3. Liang, H.C. and Thomson, B.M. Minerals and mine drainage. Water Environment Research 81, $1615-1663$ (2009).

4. Murphy, R. and Strongin, D.R. Surface reactivity of pyrite and related sulfides. Surface Science Reports 64, 1-45 (2009).

5. Tributsch, H. and Rojas-Chapana, J. Bacterial strategies for obtaining chemical energy by degrading sulfide minerals. In Biomining edited by D.E. Rawlings and D.B. Johnson, Springer, Berlin, pp 263-280 (2007).

6. Johnson, D.B. Extremophiles: Acidic environments. In Encyclopedia of Microbiology edited by M. Schaechter, Oxford, Elsevier, pp 107-126 (2009).

7. Das, B.K., Roy, A., Singh, S. and Bhattacharya, J. Eukaryotes in acidic mine drainage environments: potential applications in bioremediation. Reviews in Environmental Science and Bio/Technology 8, 257-274 (2009).

8. Watling, H.R. The bioleaching of sulphide minerals with emphasis on copper sulphides $-\mathrm{a}$ review. Hydrometallurgy 84, 81-108 (2006).

9. Pradhan, N., Nathsarma, K.C., Srinivasa Rao, K., Sukla, L.B. and Michra, B.K. Heap bioleaching of chalcopyrite: A review. Minerals Engineering 21, 355-365 (2008).

10. Puhakka, J.A., Kaksonen, A.H. and Riekkola van Hanen, M. Heap leaching of Black Schist. In Biomining edited by D.E. Rawlings and D.B. Johnson, Springer, Berlin, pp 139-151 (2007).

11. Watling, H.R. The bioleaching of nickel-copper sulphides. Hydrometallurgy 91, 70-88 (2008).

12. Morin, D.H.R. and d'Hugues, P. Bioleaching of a cobalt-containing pyrite in stirred tank reactors: a case study from laboratory scale to industrial application. In Biomining edited by D.E. Rawlings and D.B. Johnson, Springer, Berlin, pp 35-55 (2007).

13. d'Hugues, P., Joulian, C., Spolaore, P., Michel, C., Garrido, F. and Morin, D. Continuous bioleaching of a pyrite in stirred reactors: Population dynamics and exopolysaccharides production vs. bioleaching performances. Hydrometallurgy 94, 34-41 (2008). 
14. Domic, E.M. A review of the development and current status of copper bioleaching operations in Chile: 25 years of successful commercial implementation. In Biomining edited by D.E. Rawlings and D.B. Johnson, Springer, Berlin, pp 81-95 (2007).

15. Brierley, C.L. How will biomining be applied in the future? Transactions of Nonferrous Metals Society of China 18, 1302-1310 (2008).

16. du Plessis, C.A., Batty, J.D. and Dew, D.W. Commercial applications of thermophile bioleaching. In Biomining edited by D.E. Rawlings and D.B. Johnson, Springer, Berlin, pp 57-80 (2007)

17. Van Aswegen, P.C., van Niekerk, J. and Olivier, W. The BIOX ${ }^{\mathrm{TM}}$ Process for the treatment of refractory gold concentrates. In Biomining edited by D.E. Rawlings and D.B. Johnson, Springer, Berlin, pp 1-33 (2007).

18. Norris, P.R. Acidophile diversity in mineral sulfide oxidation. In Biomining edited by D.E. Rawlings and D.B. Johnson, Springer, Berlin, pp 199-216 (2007).

19. Holmes, D.S. and Bonnefoy, V. Genetic and bioinformatic insights into iron and sulfur oxidation mechanisms of bioleaching organisms. In Biomining edited by D.E. Rawlings and D.B. Johnson, Springer, Berlin, pp 281-307 (2007).

20. Johnson, D.B. and Hallberg, K.B. Techniques for detecting and identifying acidophilic mineraloxidizing organisms. In Biomining edited by D.E. Rawlings and D.B. Johnson, Springer, Berlin, pp 237-261 (2007).

21. Ferrer, M., Golyshina, O.V., Beloqui, A., Böttger, L.H., Andreu, J.M., Polaina, J., De Lacey, A.L., Trautwein, A.X., Timmis, K.N. and Golyshin, P.N. A purple acidophilic di-ferric DNA ligase from Ferroplasma. Proceedings of the National Academy of Sciences USA 105, 8878-8883 (2008).

22. Klauber, C. A critical review of the surface chemistry of acidic ferric sulphate dissolution of chalcopyrite with regards to hindered dissolution. International Journal of Mineral Processing 86, $1-17$ (2008).

23. Tributsch, H. and Rojas-Chapana, J.A. Metal sulfide semiconductor electrochemical mechanisms induced by bacterial activity. Electrochimica Acta 45, 4705-4716 (2000). 
24. Sand, W., Gehrke, T., Jozsa, P.G. and Schippers, A. (Bio)chemistry of bacterial leaching - Direct vs. indirect bioleaching. Hydrometallurgy 59, 159-175 (2001).

25. Holmes, D.S., Cárdenas, J.P., Valdés, J., Quatrini, R., Esparza, M., Osorio, H., Duarte, F., Lefimil, C. and Jedlicki, E. Comparative genomics begins to unravel the ecophysiology of bioleaching. Advanced Materials Research 71-73, 143-150 (2009).

26. Jerez, C.A. The use of genomics, proteomics and other OMICS technologies for the global understanding of biomining organisms. Hydrometallurgy 94, 162-169 (2008).

27. Clark, M.E., Batty, J.D., van Buuren, C.B., Dew, D.W. and Eamonn, M.A. Biotechnology in minerals processing: Technological breakthroughs creating value. Hydrometallurgy 83, 3-9.

28. Readett, D., Sylwestrzak, L., Franzmann, P.D., Plumb, J.J., Robertson, W.J., Gibson, J.A.E. and Watling, H. The life cycle of a chalcocite heap system. In Hydrometallurgy 2003 - Proceedings of the Fifth International Conference in honor of Professor Ian Ritchie edited by C. Young, A. Alfantazi, C. Anderson, A. James, D. Dreisinger and B. Harris, TMS, Warrendale, Volume 1, pp $365-374(2003)$

29. Schlitt, W.J. Kennecott's million-ton test heap - The active leach program. Minerals \& Metallurgical Processing 23, 1-16 (2006).

30. Rohwerder, T., Gehrke, T., Kinzler, K. and Sand, W. Bioleaching review Part A, Progress in bioleaching: fundamentals and mechanisms of bacterial metal sulfide oxidation. Applied Microbiology and Biotechnology 63, 239-248 (2003).

31. Schlitt, W.J. History of forced aeration in copper sulfide leaching. Minerals \& Metallurgical Processing 23, 57-66 (2006).

32. Plumb, J.J., Hawkes, R.B. and Franzmann, P.D. The microbiology of moderately thermophilic and transiently thermophilic ore heaps. In Biomining edited by D.E. Rawlings and D.B. Johnson, Springer, Berlin, pp 217-235 (2007).

33. Miller, P.C. The design and operating practice of bacterial oxidation plant using moderate thermophiles (The BacTech Process). In Biomining: Theory, Microbes and Industrial Processes edited by D.E.Rawlings, Springer, Berlin, pp 81-102 (1997). 
34. Heinzle, T., Miller, D. and Nagel, V. Results of an integrated pilot plant operation using the BioNIC $^{\mathrm{R}}$ process to produce nickel metal. In Biomine'99 and Water Management in Metallurgical Operations, AusIMM, Melbourne, pp 16-25 (1999).

35. Dew, D.W., Lawson, E.N. and Broadhurst, J.L. The BIOX process for biooxidation of gold bearing ores or concentrates. In Biomining: Theory, Microbes and Industrial Processes edited by D.E. Rawlings, Springer, New York, pp. 45-80 (1997).

36. Rawlings, D.E. Heavy metal mining using microbes. Annual Review in Microbiology 56, 65-91 (2002).

37. Chong, N., Karamanev, D.G. and Margaritis, A. effect of particle-particle shearing on the bioleaching of sulfide minerals. Biotechnology and Bioengineering 80, 349-357 (2002).

38. Deveci, H. Effect of particle size and shape of solids on the viability of acidophilic bacteria during mixing in stirred tank bioreactors. Hydrometallurgy 71, 385-396 (2004).

39. Watling, H.R., Elliot, A.D., Maley, M., van Bronswijk, W. and Hunter, C. Leaching of a lowgrade, copper-nickel sulfide ore. 1 . Key parameters impacting on $\mathrm{Cu}$ recovery during column bioleaching. Hydrometallurgy 97, 204-212 (2009).

40. Maley, M., van Bronswijk, W. and Watling, H.R. Leaching of a low-grade, copper-nickel sulfide ore. 3. Interactions of $\mathrm{Cu}$ with selected sulfide minerals. Hydrometallurgy 98, 73-80 (2009).

41. Perpich, M.J. and Duby, P. An electrochemical and chemical study of the leaching of copper sulfides in acidified ferrous sulphate solutions. In Copper-Cobre '99: Proceedings of the international conference, Volume IV Hydrometallurgy of Copper, edited by S.K. Young, D.B. Dreisinger, R.P. Hackl and D.G. Dixon, TMS, Warrendale, pp. 213-229 (1999).

42. Hallberg, K.B. New perspectives in mine water microbiology. Advanced Materials Research 7173, 29-36 (2009)

43. Hallberg, K.B., Amouric, A., Brochier-Armanet, C., Bonnefoy, V. and D.B. Johnson. Physiological and phylogenetic heterogeneity among iron-oxidizing Acidithiobacillus spp., and characteristics of the novel species Acidithiobacillus ferrivorans. Advanced Materials Research 71-73, 167-170 (2009). 
44. Davis-Belmar, C.S. and Norris, P.R. Ferrous iron and pyrite oxidation by "Acidithiomicrobium" species. Advanced Materials Research 71-73, 271-274 (2009).

45. Plumb, J.J., Haddad, C.M., Gibson, J.A.E. and Franzmann, P.D. Acidianus sulfidivorans sp. nov., an extremely acidophilic, thermophilic archaeon isolated from a solfatara on Lihir Island, Papua New Guinea, and emendation of the genus description. International Journal of Systematic and Evolutionary Microbiology 57, 1418-1423 (2007).

46. Breuker, A., Blazejak, A., Bosecker, K. and Schippers, A. diversity of iron oxidizing bacteria from various sulfidic mine waste dumps. Advanced Materials Research 71-73, 47-50 (2009).

47. Halinen, A.-K., Rahunen, N., Kaksonen, A.H. and Puhakka, J.A. Heap bioleaching of a complex sulfide ore Part 1: effect of $\mathrm{pH}$ on metal extraction and microbial composition in $\mathrm{pH}$ controlled columns. Hydrometallurgy 98, 92-100 (2009).

48. Galleguillos, P., Remonsellez, F., Galleguillos, F., Guiliani, N., Castillo, D. and Demergasso, C. Identification of differentially expressed genes in an industrial bioleaching heap processing lowgrade copper sulphide ore elucidated by RNA arbitrarily primed polymerase chain reaction. Hydrometallurgy 94, 148-154 (2008).

49. Coram, N.J. and Rawlings, D.E.. Molecular relationship between two groups of the genus Leptospirillum and finding that Leptospirillum ferriphilum sp. nov. dominates South African commercial biooxidation tanks that operate at $40^{\circ} \mathrm{C}$. Applied and Environmental Microbiology 68, 838-845 (2002).

50. Galleguillos, P.A., Hallberg, K.B. and Johnson, D.B. Microbial diversity and genetic response to stress conditions of extremophilic bacteria isolated from the Escondida copper mine. Advanced Materials Research 71-73, 55-58 (2009).

51. Zepeda, V., Galleguillos, F., Urtuvia, V., Molina, J. and Demergasso, C. Comparison between the bacterial populations from Solutions and minerals in $1 \mathrm{~m}$ test columns and the industrial low grade copper sulphide bioleaching process in the Escondida Mine, Chile. Advanced Materials Research 71-73, 63-66 (2009). 
52. Okibe, N., Gericke, M., Hallberg, K.B. and Johnson, D.B. Enumeration and characterization of acidophilic microorganisms isolated from a pilot plant stirred-tank bioleaching operation. Applied and Environmental Microbiology 69, 1936-1943 (2003).

53. Watkin, E.L.J., Keeling, S.E., Perrot, F.A., Shiers, D.W., Palmer, M.-L. and Watling, H.R. Metals tolerance in moderately thermophilic isolates from a spent copper sulfide heap, closely related to Acidithiobacillus caldus, Acidimicrobium ferrooxidans and Sulfobacillus thermosulfidooxidans. Journal of Industrial Microbiology and Biotechnology 36, 461-465 (2009).

54. Clark, D.A. and Norris, P.R. Acidimicrobium ferrooxidans gen. nov., sp. nov.: mixed culture ferrous iron oxidation with Sulfobacillus species. Microbiology 142, 785-790 (1996).

55. Cleaver, A.A., Burton, N.P. and Norris, P.R. A novel Acidimicrobium species in continuous cultures of moderately thermophilic, mineral-sulfide-oxidizing acidophiles. Applied and Environmental Microbiology 73, 4297-4299 (2007).

56. Hawkes, R.B., Franzmann, P.D. and Plumb, J.J. Moderate thermophiles including "Ferroplasma cupricumulans" sp. nov. dominate an industrial-scale chalcocite heap bioleaching operation. Hydrometallurgy 83, 229-236 (2006).

57. Tan, G.L., Shu, W.S., Hallberg, K.B., Li, F., Lan, C.Y., Zhou, W.H., Huang, L.N. Culturable and molecular phylogenetic diversity of microorganisms in an open-dumped extremely acidic $\mathrm{Pb} / \mathrm{Zn}$ mine tailings. Extremophiles 12, 657-664 (2008).

58. Johnson, D.B., Joulian, C., d'Hugues, P. and Hallberg, K.B. Sulfobacillus benefaciens sp. nov., an acidophilic facultative anaerobic Firmicute isolated from mineral bioleaching reactors. Extremophiles 12, 789-798 (2008).

59. Liu, X., Chen, B. and Wen, J. Acidithiobacillus played important role in Zijinshan commercial low-grade copper bioleaching heap. Advanced Materials Research 71-73, 51-54 (2009).

60. Dopson, M. and Lindstrom, E.B. Analysis of community composition during moderately thermophilic bioleaching of pyrite, arsenical pyrite and chalcopyrite. Microbial Ecology 48, 19-28 (2004). 
61. Bogdanova, T.I., Tsaplina, I.A., Kondrat'eva, T.F., Duda, V.I., Suzina, N.E., Melamud, V.S., Tourova, T.P. and Karavaiko, G.I. Sulfobacillus thermotolerans sp. nov., a thermotolerant, chemolithotrophic bacterium. International Journal of systematic and Evolutionary Microbiology 56, 1039-1042 (2006).

62. Kinnunen, P.H.M. and Puhakka, J.A. Characterization of iron- and sulphide mineral-oxidizing moderately thermophilic acidophilic bacteria from an Indonesian auto-heating copper mine waste heap and a deep South African gold mine. Journal of Industrial Microbiology and Biotechnology 39, 409-414 (2004).

63. Foucher, S., Battaglia-Brunet, F., d'Hugues, P., Clarnes, M., Godon, J.J. and Morin, D. Evolution of the bacterial population during the batch leaching of a cobaltiferous pyrite in a suspendedsolids bubble column and comparison with a mechanically agitated reactor. Hydrometallurgy 71, $5-12(2003)$.

64. Melamud, V.S., Pivovarova, T.A., Tourova, T.P., Kolganova, T.V., Osipov, G.A., Lysenko, A.M., Kondrat'eva, T.F. and Karavaiko, G.I. Sulfobacillus sibiricus sp. nov., a new moderately thermophilic bacterium. Microbiology 72, 605-612 (2003).

65. Dinkla, I.J.T., gericke, M., Geurkink, B.K. and Hallberg, K.B. Acidianus brierleyi is the domiant thermoacidophile in a bioleaching community processing chalcopyrite containing concentrates at 70 C. Advanced Materials Research 71-73, 67-70 (2009).

66. Norris, P.R., Burton, N.P. and Foulis, N.A.M. Acidophiles in bioreactor mineral processing. Extremophiles 4, 71-76 (2000).

67. Johnson, D.B. Biodiversity and interactions of acidophiles: Key to understanding and optimizing microbial processing of ores and concentrates. Transactions of the Nonferrous Metals Society of China 18, 1367-1373 (2008).

68. Mikkelson, D., Kappler, U., McEwan, A.G. and Sly, L.I. Archaeal diversity in two thermophilic chalcopyrite bioleaching reactors. Environmental Microbiology 8, 2050-2055 (2006). 
69. Mikkelsen, D., Kappler, U., McEwan, A.G. and Sly, L.I. Probing the archaeal diversity of a mixed thermophilic bioleaching culture by TGGE and FISH. Systematic and applied Microbiology 32, 501-513 (2009).

70. Rawlings, D.E., Tributsch, H. and Hansford, G.S. Reasons why 'Leptospirillum'-like species rather than Thiobacillus ferrooxidans are the domiant iron-oxidizing bacteria in many commercial processes for the biooxidation of pyrite and related ores. Microbiology 145, 5-13 (1999).

71. Watling, H.R., Perrot, F.A. and Shiers, D.W. Comparison of selected characteristics of Sulfobacillus species and review of their occurrence in acidic and bioleaching environments. Hydrometallurgy 93, 57-65 (2008).

72. Imperio, T., Viti, C. and Marri, L. Alicyclobacillus pohliae sp. nov., a thermophilic, endosporeforming bacterium isolated from geothermal soil of the north-west slope of Mount Melbourne (Antarctica). International Journal of Systematic and Evolutionary Microbiology 58, 221-225 (2008).

73. Demergasso, C.S., Galleguillos P., P.A., Escudero G., L.V., Zepeda A., V.J., Castillo, D. and Casamayor, E.O. Molecular characterization of microbial populations in a low-grade copper ore bioleaching test heap. Hydrometallurgy 80, 241-253 (2005).

74. Remonsellez, F., Moreno-Paz, M., Parro, V. and Demergasso, C. Differential gene expression of industrial bioleaching transcriptomes by Leptospirillum ferrooxidans DNA microarray. Advanced Materials Research 71-73, 227-230 (2009).

75. Soto, P., Meneses, C., Contador, Y., Galleguillos, P., Demergasso, C. and Seron, M. Characterization of oxidizing activity of a microbiol community in an industrial bioleaching heap. Advanced Materials Research 71-73, 59-62 (2009).

76. Druschel, G.K., Baker, B.J., Gihring, T.M. and Banfield, J.F. Acid mine drainage biogeochemistry at Iron Mountain, California. Geochemical Transactions 5(2), 13-32 (2004).

77. Nieto, J.M., Sarmiento, A.M., Olias, M., Canovas, C.R., Riba, I. Kalman, J and Delvalls, T.A. Acid mine drainage pollution in the Tinto and Odiel Rivers (Iberian Pyrite Belt, SW Spain) and 
bioavailability of the transported metals to the Huelva Estuary. Environment International 33, 445-455 (2007).

78. Pinches, A., Huberts, R., Neale, J.W. and Dempsey, P. the MINBACTM bacterial oxidation process. In Proceedings XV CMMI Congress (Johannesburg, RSA) Volume 2, Metals technology and Extractive Metallurgy edited by H.W. Glen, South African Institute of Mining and Metallurgy, Marshalltown, RSA pp. 377-392 (1994).

79. Personal communications: R.P. Hackl, H. Holle, C.J. Hunter, P.C. Miller, M. O’Shea, P. Spolaore

80. De, G.C., Oliver, D.J. and Pesic, B.M. Effect of heavy metals on the ferrous ion oxidizing ability of Thiobacillus ferrooxidans. Hydrometallurgy 44, 53-63 (1997).

81. Tuovinen, O.H., Niemela, S.I. and Gyllenberg, H. Tolerance of Thiobacillus ferrooxidans to some metals. Antonie van Leeuwenhoek Journal of Microbial Serology 37, 489-496 (1971).

82. Baillet, F., Magnin, J.P., Cheruy, A. and Ozil, P. Chromium precipitation by the acidophilic bacterium Thiobacillus ferrooxidans. Biotechnology Letters 20, 95-99 (1998).

83. Leduc, L.G., Ferroni, G.D. and Trevors, J.T. Resistance to heavy metals in different strains of Thiobacillus ferrooxidans. World Journal of Microbiology and Biotechnology 13, 453-455 (1997).

84. Chisholm, I.A., Leduc, L.G. and Ferroni, G.D. metals resistance and plasmid DNA in Thiobacillus ferrooxidans. Antonie van Leeuwenhoek International Journal of General and Molecular Microbiology 73, 245-254 (1998).

85. Brahmaprakash, G.P., Devasia, P., Jagadish, K.S., Natarajan, K.A. and Rao, G.R. Deveopment of Thiobacillus ferrooxidans ATCC 19859 strains tolerant to copper and zinc. Bulletin of Materials Science 10, 461-465 (1988).

86. Natarajan, K.A. and Iwasaki, I. Role of galvanic interactions in the bioleaching of Duluth gabbro copper-nickel sulfides. Separation Science Technology 18, 1095-1111 (1983). 1983

87. Hallberg, K.B., Dopson, M. and Lindstrom, E.B. Arsenic toxicity is not due to a direct effect on the oxidation of reduced inorganic sulfur compounds by Thiobacillus caldus. FEMS Microbiology Letters 145, 409-414 (1996). 
88. Ojumu, T.V., Petersen, J. and Hansford, G.S. the effect of dissolved cations on microbial ferrousiron oxidation by Leptospirillum ferriphilum in continuous culture. Hydrometallurgy 94, 69-76 (2008).

89. Nurmi, P., Ozkaya, B., Kaksonen, A.H., Tuovinen, O.H. and Puhakka, J.A. Inhibition kinetics of iron oxidation by Leptospirillum ferriphilum in the presence of ferric, nickel and zinc ions. Hydrometallurgy 97, 137-145 (2009).

90. Sampson, M.I. and Phillips, C.V. Influence of base metals on the oxidising ability of acidophilic bacteria during the oxidation of ferrous sulphate and mineral sulfide concentrates, using mesophiles and moderate thermophiles. Minerals Engineering 14, 317-340 (2001).

91. Mahapatra, N.R. and Banerjee, P.C. Extreme tolerance to cadmium and high resistance to copper, nickel and zinc in different Acidiphilium strains. Letters in Applied Microbiology 23, 393-397 (1996).

92. Baker-Austin, C., Dopson, M., Wexler, M., Sawyers, R.G. and Bond, P.L. Molecular insight into extreme copper resistance in the extremophilic archaeon 'Ferroplasma acidarmanus' Fer1. Microbiology 151, 2637-2646 (2005).

93. Baker-Austin, C., Dopson, M., Wexler, M., Sawers, R.G., Stemmler, A., Rosen, B.P. and Bond, P.L. Extreme arsenic resistance by the acidophilic archaeon 'Ferroplasma acidarmanus' Fer1. Extremophiles 11, 425-434 (2007).

94. Grogan, D.W. Phenotypic characterization of the archaeobacterial genus Sulfolobus. Comparisons of five wild type strains. Journal of Bacteriology 171, 6710-6719 (1989).

95. Huber, H. and Stetter, K.O. Thiobacillus prosperus sp. nov. represents a new group of halotolerant metal-mobilizing bacteria isolated from a marine geothermal field. Archives of Microbiology 151, 479-485 (1989).

96. Silver, S. and Phung, L.T. Bacterial heavy metal resistance: New surprises. Annual Review in Microbiology 50, 753-789 (1996). 
97. Dopson, M., Baker-Austin, C., Koppineedi, P.R. and Bond, P.L. Growth in sulfidic environments: metal resistance mechanisms in acidophilic micro-organisms. Microbiology 149, 1959-1970 (2003).

98. Rawlings, D.E. Relevance of cell physiology and genetic adaptability of biomining microorganisms to industrial processes. In Biomining edited by D.E. Rawlings and D.B. Johnson, Springer, Berlin, pp 177-198 (2007).

99. Navarro, C.A., Orellana, L.H., Mauriaca, C. And Jerez, C.A. Transcriptional and functional studies of Acidithiobacillus ferrooxidans genes related to survival in the presence of copper. Applied and Environmental Microbiology 75, 6102-6109 (2009).

100. Tian, J., Wu, N.F., Li, J., Liu, Y.J., Guo, J., Yao, B. and Fan, Y.L. Nickel-resistant determinant from Leptospirillum ferriphilum. Applied Environmental Microbiology 73, 2364-2368 (2007).

101. Blight, K.R. and Ralph, D.E. Effect of ionic strength on iron oxidation with batch cultures of chemolithotrophic bacteria. Hydrometallurgy 73, 325-334 (2004).

102. Blight, K.R. and Ralph, D.E. Aluminium sulphate and potassium nitrate effects on batch culture of iron oxidising bacteria. Hydrometallurgy 92, 130-134 (2008).

103. Shiers, D.W., Blight, K.R. and Ralph, D.E. Sodium sulphate and sodium chloride effects on batch culture of iron oxidising bacteria. Hydrometallurgy 80, 75-82 (2005).

104. Escobar, B., Alcaino, E., Brusadelli, P., Elgueta, J.P. and Salazar, O. Dynamics of biodiversity in bioleaching processes. In Hydrocopper 2009 edited by E. Domic and J Casas, Gecamin, Santiago, pp 342-351 (2009).

105. Li, H. and Ke, J.-J. Influence of $\mathrm{Cu}^{2+}$ and $\mathrm{Mg}^{2+}$ on the growth and activity of $\mathrm{Ni}^{2+}$ adapted Thiobacillus ferrooxidans. Minerals Engineering 14, 113-116 (2001).

106. Ojumu TV, Petersen, J. and Hansford, G.S. The effect of aluminium and magnesium sulphate on the rate of ferrous iron oxidation by Leptospirillum ferriphilum in continuous culture. Advanced Materials Research 20-21, 159-169 (2007). 
107. Suzuki, I., Lee, D., Mackay, B., Harahuc, L. and Oh, J.K. Effect of various anions, pH, and osmotic pressure on oxidation of elemental sulfur by Thiobacillus thiooxidans. Applied and Environmental Microbiology 65, 5163-5168 (1999).

108. Zammit, C.M., Mutch, L.A., Watling, H.R., and Watkin, E.L.J. The characterization of salt tolerance in biomining microorganisms and the search for novel salt tolerant strains. Advanced Materials Research 71-73, 283-286 (2009).

109. Alexander, B., Leach, S. and Ingledew, W.J. The relationship between chemiosmotic parameters and sensitivity to anions and organic acids in the acidophile Thiobacillus ferrooxidans. Journal of General Microbiology 133, 1171-1179 (1987).

110. Ferguson, S.J. and Ingledew, W.J. Energetic problems faced by micro-organisms growing or surviving on parsimonious energy sources at acidic $\mathrm{pH}$ : I. Acidithiobacillus ferrooxidans as a paradigm. Biochimica et Biophysica Acta - Bioenergetics 1777, 1471-1479 (2008).

111. Davis-Belmar, C.S., Nicolle, J. Le C. and Norris, P.R., Ferrous iron oxidation and leaching of copper ore with halotolerant bacteria in ore columns. Hydrometallurgy 94, 144-147 (2008).

112. Holden, P.J., Foster, L.J., Neilan, B.A. and Vu, Q.M. Characterisation of novel salt tolerant ironoxidising bacteria. In Proceedings of the International Biohydrometallurgy Symposium (Belo Horizonte) edited by V.S.T. Ciminelli, and O. Garcia, Elsevier, Amsterdam, Part A, pp 283-290 (2001).

113. Kamimura, K., Kunomura, K. and Sugio, T. Isolation and characterization of a marine ironoxidizing bacterium requiring $\mathrm{NaCl}$ for growth. In Proceedings of the International Biohydrometallurgy Symposium (Madrid) edited by R. Amils and A. Ballester, Elsevier, Amsterdam, Part A, pp 741-746 (1999).

114. Kamimura, K., Higashino, E., Moriya, S. and Sugio, T. Marine acidophilic sulfur-oxidizing bacterium requiring salts for the oxidation of reduced inorganic sulfur compounds. Extremophiles 7, 95-99 (2003). 
115. Kelly, D.P., Stackebrandt, E., Burghardt, J. and Wood, A.P. Confirmation that Thiobacillus halophilus and Thiobacillus hydrothermalis are distinct species within the $\gamma$-subclass of the Proteobacteria. Archives of Microbiology 170, 138-140 (1998).

116. Kelly, D.P. and Wood, A.P. Reclassification of some species of Thiobacillus to the newly designated genera Acidithiobacillus gen. nov., Halothiobacillus gen. nov. and Thermithiobacillus gen. nov. International Journal of Systematic and Evolutionary Microbiology 50, 511-516 (2000).

117. Franzmann, P.D., Haddad, C.M., Hawkes, R.B., Robertson, W.J. and Plumb, J.J. Effects of temperature on the rates of iron and sulfur oxidation by selected bioleaching bacteria and Archaea: application of the Ratkowsky equation. Minerals Engineering 18, 1304-1314 (2005).

118. Batty, J.D. and Rorke, G.V. Development and commercial demonstration of the BioCOP ${ }^{\mathrm{TM}}$ thermophile process. Hydrometallurgy 83, 83-89 (2006).

119. Hunter, C. BioheapTM leaching of a primary nickel-copper sulphide ore. In ALTA 2002 NickelCobalt -8 Technical Proceedings, ALTA Metallurgical Services, Melbourne, 11p.(2002).

120. Logan, T.C., Seal, T. and Brierley, J.A., Whole-ore heap biooxidation of sulfidic gold-bearing ores. In Biomining edited by D.E. Rawlings and D.B. Johnson, Springer, Berlin, pp 113-138 (2007).

121. Rawlings, D.E. and Johnson, D.B. The microbiology of biomining: development and optimization of mineral-oxidizing microbial consortia. Microbiology 153, 315-324 (2007).

122. Du Plessis, C.A. Delivery system for heap bioleaching. US Patent application 2004/0235141 A1 (2004).

123. Brierley, J.A. response of microbial systems to thermal stress in heap-biooxidation pretreatment of refractory gold ores. Hydrometallurgy 71, 13-19 (2003).

124. Mutch, L.A., Watling, H.R. and Watkin, E.L.J. Microbial population dynamics of inoculated lowgrade chalcopyrite bioleaching columns. Hydrometallurgy (submitted).

125. Large, A.T. and Lund, P.A. Archaeal chaperonins. Frontiers in Science 14, 1304-1324 (2009).

126. Lund, P.A. Multiple chaperonins in bacteria - why so many? FEMS Microbiology Reviews 33, 785-800 (2009). 
127. Jerez, C.A. The heat-shock response in mesoacidophilic and thermoacidophilic chemolithotrophic bacteria. FEMS Microbiology Letters 56, 289-293 (1988).

128. Alvarez, S. and Jerez, C.A. Molecular aspects of the stress response in Thiobacillus ferrooxidans and other biomining microorganisms. In Biohydrometallurgy 1989: Proceedings of the International Biohydrometallurgy Symposium, edited by J. Salley, R.G.L. McCready and P.L. Wichlacz, Department of Supplied and Services, Government of Canada, Ottawa, pp. 439-449 (1989).

129. Varela, P. and Jerez, C.A. Identification and characterization of Groel and DNAK homologs in Thiobacillus ferrooxidans. FEMS Microbiology Letters 98, 149-153 (1992).

130. Xiao, S., Chao, J., Wang, W., Fang, F., Qiu, G. and Liu, X. Real-time PCR analysis of the heat shock response of Acidithiobacillus ferrooxidans. Folia Biologica 55(1), 1-6 (2009).

131. Hubert, W.A., Leduc, L.G. and Ferroni, G.D. Heat and cold shock responses in different strains of Thiobacillus ferrooxidans. Current Microbiology 31, 10-14 (1995).

132. Modak, J.M., Natarajan, K.A. and Mukhopadhyay, S. Development of temperature-tolerant strains of Thiobacillus ferrooxidans to improve bioleaching kinetics. Hydrometallurgy 42, 51-61 (1996).

133. Baker -Austin, C. and Dopson, M. Life in acid: $\mathrm{pH}$ homeostasis in acidophiles. TRENDS in Microbiology 15 165-171 (2007).

134. Slonczewski, J.L., Fujisawa, M., Dopson, M. and Krulwich, T.A. Cytoplasmic pH measurement and homeostasis in bacteria and archaea. Advances in Microbial Physiology 55, 1-79 (2009).

135. Chilean Copper Commission. The Chilean sulfuric acid market estimations through 2015. Report No. DE / 05 / 2009. 30 p.

136. Yukselen, M.A. Characterization of heavy metal contaminated soils in Northern Cyprus Environmental Geology 42, 597-603 (2002).

137. Plumb, J.J., Muddle, R. and Franzmann, P.D. Effect of $\mathrm{pH}$ on rates of iron and sulfur oxidation by bioleaching organisms. Minerals Engineering 21, 76-82 (2008). 
138. Tan, Y.H., Wang, Z.-X. and Marshall, K.C. Modeling pH effects on microbial growth: a statistical thermodynamic approach. Biotechnology and Bioengineering 59, 724-731 (1998).

139. Yahya, A. and Johnson, D.B. Bioleaching of pyrite at low $\mathrm{pH}$ and low redox potentials by novel mesophilic Gram-positive bacteria. Hydrometallurgy 63, 181-188 (2002).

140. Liu, X., Shu, R., Chen, B., Wu, B. And Wen, J. Bacterial community structure change during pyrite bioleaching process: Effect of pH and aeration. Hydrometallurgy 95, 267-272 (2009).

141. Dopson, M., Baker-Austin, C., Hind, A., Bowman, J.P. and Bond, P.L. Characterization of Ferroplasma isolates and Ferroplasma acidarmanus sp. nov., extreme acidophiles from acid mine drainage and industrial bioleaching environments. Applied and Environmental Microbiology 70, 2079-2088 (2004).

142. Stott, M.B., Watling, H.R., Franzmann, P.D. and Sutton, D. The role of iron-hydroxy precipitates in the passivation of chalcopyrite during bioleaching. Minerals Engineering 13, 1117-1127 (2000).

143. Klauber, C., Parker, A., van Bronswijk, W. and Watling, H. Sulphur speciation of leached chalcopyrite surfaces as determined by X-ray photoelectron spectroscopy. International Journal of Mineral Processing 62, 65-94 (2001).

144. Goebel, B.M. and Stackebrandt, E. Cultural and phylogenetic analysis of mixed microbial populations found in natural and commercial bioleaching environments. Applied and Environmental Microbiology 60, 1614-1621 (1994).

145. Schaeffer, W.I. and Umbreit, W.W. Phosphotidylinositol as a wetting agent in sulfur oxidation by Thiobacillus thiooxidans. Journal of Bacteriology 85, 492-493 (1963)

146. Schnaitman, C. and Lundgren, D.G. Organic compounds in spent medium of Ferrobacillus ferrooxidans. Canadian Journal of Microbiology 11, 23-27 (1965).

147. Borichewski, R.M. Keto acids as growth-limiting factors in autotrophic growth of Thiobacillus thiooxidans. Journal of Bacteriology 93, 597-599 (1967). 
148. Okibe, N. and Johnson, D.B. Biooxidation of pyrite by defined mixed cultures of moderately thermophilic acidophiles in pH-controlled bioreactors: Significance of microbial interactions. Biotechnology and Bioengineering 87, 573-583 2004

149. Bacelar-Nicolau, P. and Johnson, D.B. Leaching of pyrite by acidophilic heterotrophic ironoxidizing bacteria in pure and mixed cultures. Applied and Environmental Microbiology 65, 585590 (1999).

150. Jerez, C.A. chemotactic transduction in biomining microorganisms. Hydrometallurgy 59, 347-356 (2001).

151. Valdés, J., Pedroso, I., Quatrini, R. and Holmes, D.S. Comparative genome analysis of Acidithiobacillus ferrooxidans, A. thiooxidans and A. caldus: Insights into their metabolism and ecophysiology. Hydrometallurgy 94, 180-184 (2008).

152. Aliaga Goltsman, D.S., Denef, V.J., Singer, S.W., VerBerkmoes, N.C., Lefsrud, M., Mueller, R.S., Dick, G.J., Sun, C.L., Wheeler, K.E., Zemla, A., Baker, B.J., Hauser, L., Land, M., Shah, M.B., Thelen, M.P., Hettich, R.L. and Banfield, J.F. Community genomic and proteomic analyses of chemolithotrophic iron-oxidizing "Leptospirillum rubarum” (Group II) and "Leptospirillum ferrodiazotrophum" (Group (III) bacteria in acid mine drainage biofilms. Applied and Environmental Microbiology 75, 4599-4615 (2009).

153. Sand, W. and Gehrke, T. Extracellular polymeric substances mediate bioleaching/biocorrosion via interfacial processes involving iron(III) ions and acidophilic bacteria. Research in Microbiology 157, 49-56 (2006).

154. Cruz, R., Lazaro, I., Gonzalez, I. and Monroy, M. Acid dissolution influences bacterial attachment and oxidation of arsenopyrite. Minerals Engineering 18, 1024-1031 (2005).

155. Edwards, K.J., Bond, P.L. and Banfield, J.F. Characteristics of attachment and growth of Thiobacillus caldus on sulphide minerals: a chemotactic response to sulphur minerals? Environmental Microbiology 2, 324-332 (2000). 
156. Olson, G.J., Brierley, J.A. and Brierley, C.L. Bioleaching review part B: Progress in bioleaching: applications of microbial processes by the minerals industry. Applied Microbiology and Biotechnology 63, 249-257 (2003).

157. Lawrence, J.R., Kwong, Y.T.J. and Swerhone, G.D.W. Colonization and weathering of natural sulfide mineral assemblages by Thiobacillus ferrooxidans. Canadian Journal of Microbiology 43, 178-188 (1997).

158. Echeverria, A. and Demergasso, C. Assessment of microbial adhesion in mixed cultures to sulfide minerals using CARD-FISH techniques. Advanced Materials Research 71-73, 83-86 (2009).

159. Ghauri, M.A., Okibe, N. and Johnson, D.B., Attachment of acidophilic bacteria to solid surfaces: The significance of species and strain variations. Hydrometallurgy 85, 72-80 (2007). 
Dr Helen Watling has worked in hydrometallurgy for 17 years and in biohydrometallurgy for 12 years in the roles of Project Manager and Program Leader in CSIRO Process Science and Engineering. She is currently the leader for the collaborative Parker Centre project 'Biohydrometallurgy Microenvironments'.

Dr David Ralph has taught chemistry in the degree program at Murdoch University for the last 23 years. His research interests in the aqueous chemistry of iron and its involvement with microbes and sulphidic minerals is pursued through the Parker Centre.

Dr Elizabeth Watkin teaches microbiology in the Molecular Biotechnology degree program at Curtin University and has been involved in research in the area of environmental microbiology for 15 years. Through collaborations established under the Parker Centre, the focus of her research over the past four years has been in biohydrometallurgy. 
Table 1. Iron- and sulphur-oxidising acidophiles [6, 42-45], some of which have been isolated from heap or stirred tank bioleaching reactors and others putatively identified from those habitats using molecular methods

\begin{tabular}{|c|c|c|c|c|c|}
\hline Organism & $\begin{array}{c}\text { Preferred } \\
\mathrm{T}^{\circ} \mathrm{C}^{*}\end{array}$ & $\begin{array}{c}\text { Preferred } \\
\mathrm{pH} *\end{array}$ & $\begin{array}{c}\text { Heap or } \\
\text { ROM }\end{array}$ & $\begin{array}{c}\text { Stirred } \\
\operatorname{tank}\end{array}$ & $\begin{array}{c}\text { References } \\
\text { (heaps or tanks) }\end{array}$ \\
\hline \multicolumn{6}{|l|}{$\underline{\mathrm{Fe}}^{\underline{\mathrm{II}}}$ oxidation } \\
\hline 'Ferrovum mухоғасiens' & & $>2$ & & & \\
\hline Ferrimicrobium acidiphilum & 32 & $1.7-1.8$ & $\bullet$ & & {$[46-47]$} \\
\hline Leptospirillum ferrooxidans & 37 & $1.5-1.7$ & $\bullet$ & $\bullet$ & {$[46,48-49]$} \\
\hline Leptospirillum ferriphilum & 39 & $1.4-1.8$ & $\bullet$ & $\bullet$ & {$[46,49-51]$} \\
\hline Ferroplasma acidiphilum & 40 & $1.6-1.8$ & $\bullet$ & $\bullet$ & {$[47-48,50,52]$} \\
\hline Ferrithrix thermotolerans & 40 & 1.8 & & & \\
\hline Acidimicrobium ferrooxidans & 49 & 2 & $\bullet$ & $\bullet$ & {$[53-55]$} \\
\hline Ferroplasma cupricumulans & $52-54$ & $1-1.2$ & $\bullet$ & & {$[56]$} \\
\hline \multicolumn{6}{|l|}{$\mathrm{Fe}^{\mathrm{II}}$ and $\mathrm{S}$ oxidation } \\
\hline 'Acidithiobacillus ferrivorans' & $28-33$ & 2.5 & & & \\
\hline Acidithiobacillus ferrooxidans & 30 & $2-4$ & - & $\bullet$ & {$[35,47-48,50-51,57]$} \\
\hline 'Thiomonas arsenivorans' & $20-30$ & $4-7.5$ & & & \\
\hline Thiomonas intermedia & 30 & 3.5 & & & \\
\hline Alicyclobacillus tolerans & $38-42$ & $2-2.7$ & $\bullet$ & & {$[47]$} \\
\hline Sulfobacillus benefaciens & $38-39$ & 1.5 & - & • & {$[58]$} \\
\hline Sulfobacillus thermotolerans & $44-46$ & $1.3-1.5$ & $\bullet$ & $\bullet$ & {$[47,59-61]$} \\
\hline Sulfobacillus acidophilus & 48 & $1.7-1.9$ & - & $\bullet$ & {$[55,62]$} \\
\hline Sulfobacillus thermosulfidooxidans & $50-52$ & $1.6-1.8$ & $\bullet$ & $\bullet$ & {$[53,63]$} \\
\hline Sulfobacillus sibiricus & 52 & $1.4-1.6$ & & $\bullet$ & {$[64]$} \\
\hline 'Acidithiomicrobium' spp. & 50 & $1.7-2$ & & $\bullet$ & {$[44,55]$} \\
\hline Metallosphaera hakonensis & 65 & $2.5-3$ & & & \\
\hline Acidianus brierleyi & 70 & 1.5 & & $\bullet$ & {$[65]$} \\
\hline Sulfolobus metallicus & 71 & 2 & $\bullet$ & • & {$[47,66]$} \\
\hline Acidianus sulfidivorans & 74 & $0.8-1.4$ & & & \\
\hline Metallosphaera sedula & 74 & 2 & & $\bullet$ & {$[65]$} \\
\hline \multicolumn{6}{|l|}{ S oxidation } \\
\hline$\overline{\text { Acidiphilium acidophilum }}$ & $25-30$ & $3-3.5$ & $\bullet$ & & {$[46]$} \\
\hline Acidithiobacillus albertensis & $25-30$ & $3.5-4$ & $\bullet$ & & [59] \\
\hline Acidithiobacillus thiooxidans & 33 & $1.5-2$ & $\bullet$ & $\bullet$ & {$[47-48,51,59,67]$} \\
\hline Acidithiobacillus caldus & $49-52$ & $1.8-2.2$ & - & - & {$[53,55,60]$} \\
\hline Acidicaldus organivorans & 50 & 2.5 & & & \\
\hline Hydrogenobaculum acidophilum & 65 & $3-4$ & & & \\
\hline Metallosphaera prunae & 75 & $1-4.5$ & & $\bullet$ & {$[65]$} \\
\hline Sulfolobus tokodaii & 75 & 2 & & & \\
\hline Sulfolobus shibatae & $75-80$ & $3-4$ & & $\bullet$ & [68-69] \\
\hline Acidianus infernus & 80 & 2.5 & & $\bullet$ & {$[67,69]$} \\
\hline Acidianus ambivalens & 80 & 2.5 & & & \\
\hline
\end{tabular}

* Data taken from preferred growth medium (DSMZ: www.dsmz.de/microorganisms $/ \mathrm{html} / \mathrm{strains}$ ) where not otherwise determined in our laboratories or published with the species description. 
Table 2. Comparison of leachate compositions (approximate upper limits, g/L) for heaps and tanks [12, $34,66,78-79]$

\begin{tabular}{lcc}
\hline Element/Anion & $\begin{array}{c}\text { Heap processes } \\
\text { for low-grade ore }\end{array}$ & $\begin{array}{c}\text { Stirred tank } \\
\text { processes for } \\
\text { concentrate }\end{array}$ \\
\hline Copper & 6 & 35 \\
Nickel & 5 & 25 \\
Cobalt & $<1$ & 5 \\
Zinc & 23 & 65 \\
Arsenic & & 15 \\
Iron & 25 & 60 \\
Magnesium & 10 & $<1$ \\
Aluminium & 25 & \\
Sulphate & 130 & 145 \\
\hline
\end{tabular}


Table 3. Estimated ionic strengths for CSTR bioreactors treating gold and base metal concentrates and for base-metal sulphide heaps (based on data obtained from literature and through personal communications $[12,34,66,78-79])$.

\begin{tabular}{ll}
\hline Reactor & Range of estimated ionic strengths \\
\hline CSTR Biooxidation of refractory & 1.7 to 7.0 ; high values occurred in leachates with high $\mathrm{Fe}^{3+}, \mathrm{As}(\mathrm{III})$ \\
gold concentrates (5 examples) & or $\mathrm{As}(\mathrm{V})$ and sulphate \\
CSTR Bioleaching of base metals & 4.7 to 8.2 ; high values occurred in leachates with high $\mathrm{Fe}^{3+}$ and \\
sulphides (6 examples) & sulphate \\
Heap bioleaching (10 examples) & 1.4 to 7.6 ; high values occurred in leachates with high $\mathrm{Fe}^{3+}$ and $\mathrm{Al}^{3+}$ \\
\hline
\end{tabular}


Table 4. Halo-tolerant or halophilic acidophilic strains with ability to oxidise iron(II) and / or RISCs

\begin{tabular}{|c|c|c|c|c|c|c|}
\hline Organism & $\begin{array}{l}\text { Salt \% } \\
{[o p t]}\end{array}$ & $\begin{array}{l}\text { Preferred } \\
\mathrm{T}^{\circ} \mathrm{C}\end{array}$ & $\begin{array}{c}\text { Preferred } \\
\mathrm{pH}\end{array}$ & $\mathrm{Fe}(\mathrm{II})$ & RISC & Habitat / Source \\
\hline $\begin{array}{l}\text { Thiobacillus prosperus and } \\
\text { related strains }[95,111]\end{array}$ & $\begin{array}{c}0-3.5 \\
{[0]}\end{array}$ & 37 & 2 & o & O & $\begin{array}{l}\text { Marine geothermal } \\
\text { field }\end{array}$ \\
\hline $\begin{array}{l}\text { 'Mesophilic mixed culture' } \\
\text { [108] }\end{array}$ & $\begin{array}{c}0-3 \\
{[1.25]}\end{array}$ & 30 & 2 & $\bullet$ & $\bullet$ & $\begin{array}{l}\text { Acidic saline } \\
\text { drainage }\end{array}$ \\
\hline $\begin{array}{l}\text { 'Alicyclobacillus-like' strains } \\
\text { A2-8, A19-22 and A20-24 } \\
\text { [112] }\end{array}$ & $\begin{array}{c}0.5-4 \\
{[1]}\end{array}$ & $37-44$ & $1.6-4.5$ & $\bullet$ & o & Marine sediment \\
\hline $\begin{array}{l}\text { 'Thiobacillus-like' KU2-11 } \\
\text { [113] }\end{array}$ & $\begin{array}{c}1-5 \\
{[1-2]}\end{array}$ & 30 & 2 & $\bullet$ & $\bullet$ & Seawater \\
\hline $\begin{array}{l}\text { 'Acidithiobacillus thiooxidans- } \\
\text { like' strain SH [114] }\end{array}$ & {$[2]$} & 30 & 4 & & $\bullet$ & Seawater \\
\hline $\begin{array}{l}\text { Halothiobacillus spp. } \\
\text { [115-116] }\end{array}$ & $\begin{array}{l}2.5-20 \\
{[2.5-5]}\end{array}$ & [30-40] & {$[6.5-8]$} & & $\bullet$ & $\begin{array}{l}\text { Hypersaline lake, } \\
\text { hydrothermal vent }\end{array}$ \\
\hline
\end{tabular}

o weak • strong 